\title{
SISTEM INFORMASI E-LEARNING KURSUS KOMPUTER PADA LKP OBY KOMPUTER TEMBILAHAN
}

\author{
${ }^{1}$ Edward, ${ }^{2}$ Samsudin \\ 1,2 Program Studi Sistem Informasi, Fakultas Teknik dan Ilmu Komputer \\ Universitas Islam Indragiri (UNISI) \\ JI. Provinsi No. 01 Tembilahan Hulu, Indragiri Hilir, Riau - Indonesia \\ Email:edwardwinaldi12@gmail.com,samsudin as ad@yahoo.co.id
}

\begin{abstract}
ABSTRAK
Dalam melaksanakan kegiatan belajar mengajar pada lembaga kursus, seorang instruktur pasti pernah dihadapkan pada berbagai permasalahan baik dari faktor internal maupun eksternal. Salah satu contoh nyata permasalahan dari faktor eksternal yang terjadi pada saat ini yaitu pandemi Virus Corona (COVID-19). Penyakit berbahaya yang penularannya terbilang sangat cepat membuat hampir seluruh negara memberlakukan Lockdown demi menangani penularan virus tersebut. Dengan diberlakukannya status Lockdown tersebut, ternyata berdampak bagi pendidikan khususnya kegiatan belajar mengajar. Menyikapi hal tersebut maka pemerintah menghimbau agar proses kegiatan belajar mengajar dilakukan dirumah dengan menggunakan media internet. Demi tetap berlangsungnya pembelajaran ditengah pandemi yang terjadi saat ini, peneliti yang sekaligus seorang instruktur kursus komputer pada Lembaga Kursus dan Pelatihan (LKP) Oby Komputer telah merancang sebuah website E-learning. Melalui sistem informasi Website E-Learning kursus komputer pada LKP OBY Komputer ini bertujuan untuk menganalisa, merancang dan mengimplementasikan sistem pembelajaran kursus komputer jarak jauh. Penggunaan metode Waterfall sebagai metode pengembangan sistem berfungsi sebagai sebuah mekanisme untuk mengidentifikasikan perangkat lunak, serta UML (Unified Modeling Language) sebagai pemodelan, dan menggunakan metode PIECES untuk memudahkan peneliti dalam membangun sistem.Sistem Informasi Website E-Learning kursus komputer pada LKP OBY Komputer Tembilahan dapat mempermudah para peserta didik/siswa melalukan proses pembelajaran dengan menggunakan metode daring.
\end{abstract}

Keywords: Sistem, Informasi, E-learning, Kursus, Komputer

\section{PENDAHULUAN}

Pendidikan menjadi sektor penting yang berperan dalam kebangkitan suatu bangsa dan negara. Pendidikan merupakan usaha sadar dan terencana dalam mewujudkan proses pembelajaran dan suasana belajar agar peserta didik secara aktif mengembangkan potensi diri untuk memiliki kekuatan spiritual, keagamaan, pengendalian diri, kecerdasan, kepribadian, berakhlak mulia, serta memiliki keterampilan yang diperlukan peserta didik, bermasyarakat, bangsa dan negara.[1]

Pendidikan terbagi menjadi beberapa jenis, salah satunya adalah pendidikan non formal. Pendidikan non formal merupakan salah satu dari sekian banyak istilah yang muncul dalam studi kependidikan pada akhir tahun tujuh puluhan. Istilah-istilah pendidikan yang berkembang di tingkat internasional mula saat itu adalah: pendidikan sepanjang hayat (life long education), pendidikan pembaharuan (recurrent education), pendidikan abadi (permanent education), pendidikan informal (informal education), pendidikan masyarakat (community education), pendidikan perluasan (extention education), pendidikan massa (mass education), pendidikan sosial (social education), pendidikan orang dewasa (adult education), dan pendidikan berkelanjutan (continuing education).[2] 
Dalam melaksanakan kegiatan belajar mengajar pada lembaga kursus, seorang instruktur pasti pernah dihadapkan pada berbagai permasalahan baik dari faktor internal maupun eksternal. Salah satu contoh nyata permasalahan dari faktor eksternal yang terjadi pada saat ini yaitu pandemi Virus Corona (COVID-19). Penyakit berbahaya yang penularannya terbilang sangat cepat membuat hampir seluruh negara memberlakukan Lockdown demi menangani penularan virus tersebut. Dengan adanya status Lockdown tersebut, ternyata berdampak bagi pendidikan khususnya kegiatan belajar mengajar. Setiap sekolah dan instansi terkait seperti lembaga kursus harus diliburkan untuk kegitan tatap muka sampai pada tanggal yang belum ditentukan. Menyikapi hal tersebut maka pemerintah menghimbau agar proses kegiatan belajar mengajar dilakukan dirumah dengan menggunakan media internet.

Menurut Ariyono setiawan Dkk [3] Definisi dari E-learning adalah proses instruksi yang melibatkan penggunaan peralatan elektronik dalam menciptakan, membantu perkembangan, menyampaikan, menilai dan memudahkan suatu proses belajar mengajar dimana siswa sebagai pusatnya serta dilakukan secara interaktif kapanpun dan dimanapun. Khoe Yao Tung dalam Hasbullah [4] mengatakan bahwa setelah kehadiran instruktur dalam arti sebenarnya, internet akan menjadi suplemen dan komplemen dalam menjadikan wakil guru yang mewakili sumber belajar yang penting di dunia. Cisco (2001) sebagaimana dikutip Hasbullah [4] menjelaskan filosofi e-learning sebagai berikut :1) E-learning tidak berarti menggantikan model belajar konvensional di dalam kelas,tetapi memperkuat model belajar tersebut melalui pengayaan content dan pengembangan teknologi pendidikan.2) E-learning tidak berarti menggantikan model belajar konvensional di dalam kelas,tetapi memperkuat model belajar tersebut melalui pengayaan content dan pengembangan teknologi pendidikan. Demi tetap berlangsungnya pembelajaran ditengah pandemi yang terjadi saat ini, peneliti yang sekaligus seorang instruktur kursus komputer pada Lembaga Kursus dan Pelatihan (LKP) Oby Komputer telah merancang sebuah website E-learning untuk pembelajan kursus komputer berbasis daring.

\section{TINJAUAN PUSTAKA}

Berikut ditampilkan beberapa kajian literatur yang peneliti kumpulkan sebagai landasan teoritik yang dijadikan pedoman sumber karya ilmiah dalam penelitian ini:

\section{Tabel 1 Tinjauan Pustaka}

\begin{tabular}{|c|c|c|}
\hline Peneliti & Judul & Hasil \\
\hline $\begin{array}{l}\text { Harni Kusniyati } \\
\text { dan Yoga } \\
\text { Hapsara } \\
\text { Mursidigama }\end{array}$ & $\begin{array}{l}\text { Aplikasi Kursus Komputer } \\
\text { Online menggunakan PHP } \\
\text { pada Lembaga Kursus } \\
\text { Komputer Yogz Course [5] }\end{array}$ & $\begin{array}{l}\text { Aplikasi ini dibuat untuk } \\
\text { mempermudah pengguna, } \\
\text { baik super admin, trainer, peserta dan } \\
\text { calon peserta dalam mendapatkan } \\
\text { informasi dan mengikuti proses belajar } \\
\text { mengajar secara online }\end{array}$ \\
\hline $\begin{array}{l}\text { Indra Wijaya dan } \\
\text { Abdul } \\
\text { Hafis Lubis }\end{array}$ & $\begin{array}{l}\text { Perancangan dan Pembuatan E- } \\
\text { learning berbasis Moodle Pada } \\
\text { Mata Pelajaran } \\
\text { Keterampilan Komputer dan } \\
\text { Pengelolaan Informasi (KKPI) [6] }\end{array}$ & $\begin{array}{l}\text { Media E-learning ini adalah media yang } \\
\text { digunakan untuk membantu siswa } \\
\text { dalam } \\
\text { belajar dengan memanfaatkan media } \\
\text { berbasis Moodle }\end{array}$ \\
\hline $\begin{array}{l}\text { Immanuel } \quad H \quad G \\
\text { Manurung }\end{array}$ & $\begin{array}{l}\text { Sistem Informasi Lembaga } \\
\text { Kursus dan Pelatihan (LKP) } \\
\text { City Com berbasis Web } \\
\text { Menggunakan PHP dan MySQL } \\
\text { [7] }\end{array}$ & $\begin{array}{l}\text { Dengan adanya sistem } \\
\text { informasi ini, user tidak lagi } \\
\text { mengalami kesulitan dalam mencari } \\
\text { tahu tentang Lembaga Kursus dan Pel } \\
\text { atihan (LKP) City Com Teluk Dalam }\end{array}$ \\
\hline
\end{tabular}




\section{METODE PENELITIAN}

\subsection{Kerangka Penelitian}

Sebelum memulai penelitian, peneliti akan melakukan beberapa tahap yang akan dilakukan dalam pengumpulan data dan informasi terkait dengan judul yang diteliti, tahap tersebut akan dipaparkan sebagai berikut:

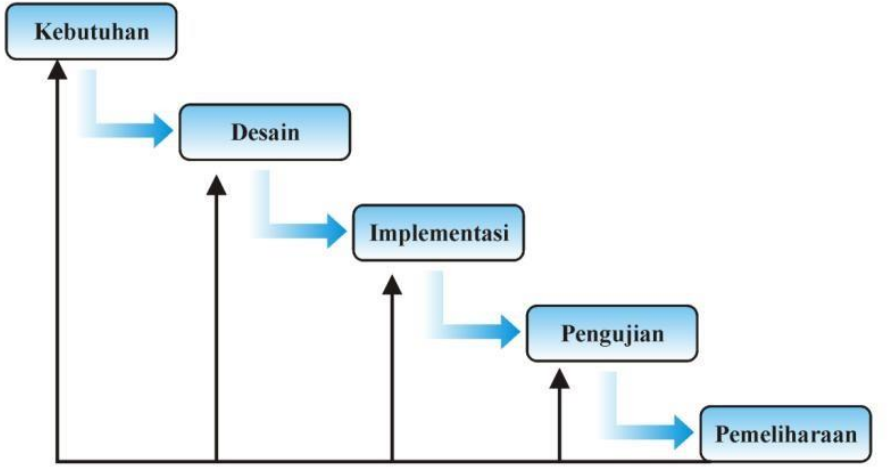

\section{Gambar 1. Alur penelitian menggunakan metode waterfall}

Pada gambar 1. digambarkan bahwa penelitian menggunakan metode waterfall. Dibawah ini akan dijelaskan secara rinci lagi bagaimana pengumpulan data, analisa sistem apa yang dipakai, perancangan sistem, dan pengujian apa yang digunakan. Berikut ini penjelasan mengenai alur penelitian tersebut :

\subsubsection{Pengumpulan Data (Kebutuhan)}

Pengumpulan data yang dilakukan ialah wawancara, observasi dan juga melakukan studi literatur.Pada penelitian ini dilakukan pengamatan secara lansung di lembaga terkait. Pada tahap studi literatur, peneliti mencari sumber-sumber tulisan berupa jurnal ataupun buku yang berhubungan dengan penelitian dan perancangan program yang digunakan sebagai referensi pada penelitian yang sedang dilakukan.

1. Observasi (Pengamatan)

Pada metode ini, peneliti melakukan pengamatan langsung di LKP OBY Komputer.Kemudian peneliti juga melakukan pengamatan pada data pembelajaran di LKP OBY Komputer guna untuk mendapatkan data resmi dari lembaga yang bersangkutan.

2. Wawancara

Pada metode ini, peneliti melakukan wawancara kepada Bapak Ridwan.M, ST selaku pimpinan LKP OBY Komputer yang beralamat di Jl.Kapten Mukhtar Tembilahan, serta kepada salah satu peserta didik yang mendaftarkan diri untuk mengikuti kursus di LKP OBY Komputer dengan menggunakan kuisioner untuk mendapatkan informasi.

3. Studi Literatur

Pada metode ini, peneliti mencari sumber-sumber tulisan berupa jurnal yang berhubungan dengan penelitian dan berhubungan dengan perancangan program yang digunakan sebagai referensi pada penelitian yang sedang dilakukan.

\subsubsection{Analisis Perancangan (Desain)}

Berdasarkan hasil pengamatan serta wawancara yang telah dilakukan, peneliti memutuskan menggunakan analisa PIECES pada penelitian ini, dengan maksud untuk menyimpulkan masalah utama yang ada pada studi kasus secara jelas dan hasil analisis dapat dirumuskan menjadi berbagai usulan untuk membantu perancangan sistem yang lebih baik. Untuk mengidentifikasi masalah, maka harus dilakukan analisis terhadap kinerja, informasi, ekonomi, pengendalian, efisiensi, dan pelayanan. Panduan ini dikenal dengananalisis PIECES (Performance, Information, Economic, Control, Efficiency, Service). Penguraian suatu sistem informasi yang sudah utuh kedalam 
bagian-bagian komponennya dengan tujuan dapat menidentifikasi. Dan mengevaluasi berbagai macam permasalahan maupun hambatan yang terjadi pada sistem sehingga nantinya dapat dilakukan perbaikan atau pengembangan.

\subsubsection{Analisis Perancangan Sistem}

Perancangan Sistem Informasi E-learning kursus komputer di LKP OBY Komputer ini penulis menggunakan metode analisa UML, sebagai sarana perancangan sistem yang akan dibangun.

\subsubsection{Pengimplementasian Sistem (Implementasi)}

Proses pengimplementasian spesifikasi sistem berdasarkan hasil analisis dan perancangan sistem yang akan dibuat. Pada tahap ini penulis mengimplementasikan sistem dengan membagi menjadi 3 bagian, yaitu : perangkat keras (hardware), perangkat lunak (software)dan pengguna (brainware).

\subsubsection{Validasi (Pengujian Sistem)}

Pengujian sistem yang digunakan dalam penelitian ini adalah pengujian sistem Black Box \& White Box.

1. Pengujian Sistem Black Box

Black Box Testing dilakukan pengujian yang didasarkan pada detail aplikasi seperti tampilan aplikasi, fungsi-fungsi yang ada pada aplikasi dan kesesuaian alur fungsi dengan bisnis proses yang diinginkan oleh customer. Pengujian sistem Black-box ini lebih menguji tampilan luar(Interface) dari suatu aplikasi agar mudah digunakan oleh Customer. Pengujian ini tidak melihat dan menguji Source Code program. Pengujian sistem Black-box bekerja dengan mengabaikan struktur control sehingga perhatianya hanya terfokus pada informasi domain.

2. Pengujian Sistem White Box

White Box Testing adalah salah satu cara untuk menguji suatu aplikasi atau software dengan melihat modul untuk memeriksa dan menganalisis kode program ada yang salah atau tidak. Jika modul ini dan telah diproduksi dalam output yang tidak memenuhi persyaratan, kode aka dikompilasi ulang dan diperiksa lagi sampai mencapai apa yang diharapkan singkatnya White Box Testing ini menguji dengan cara melihat Pure Code (Coding) dari suatu aplikasi/software yang diuji tanpa memperdulikan Tampilan dari aplikasi tersebut.

\section{HASIL DAN PEMBAHASAN}

\subsection{Pembahasan}

Tahap analisa sistem merupakan tahap yang kritis dan sangat penting karena kesalahan pada tahap ini akan menyebabkan kesalahan di tahap selanjutnya. Dalam pembuatan website ELearning kursus komputer pada LKP OBY Komputer ini peneliti menggunakan analisa PIECES (Performance, Information, Economic, Control, Efficiency, Service)untuk menganalisa beberapa hal yang dari situ akan disimpulkan masalah utama yang ada di studi kasus secara jelas dari hasil analisis akan dapat dirumuskan berbagi usulan untuk membantu perancangan sistem yang lebih baik, seperti yang dijelaskan berikut :

a. Performance Analysis (Analisa Kinerja

Dimasa pandemi Virus Covid-19 yang belum mereda sampai saat ini, sangat berpengaruh dengan peningkatan calon peserta didik karena rasa khawatir khususnya dari pihak orangtua jika harus melakukan kursus secara tatap muka. Dengan adanya pembelajaran daring menggunakan Website E- Learning ini akan menjadi pilihan terbaik bagi lembaga untuk tetap melangsungkan kegiatan kursus. Analisa kinerja pada sistem yang lama juga masih kurang effektif karena pada beberapa kasu yang sering terjadi disaat pembelajaran tatap muka, yaitu ketika instruktur harus mengikuti kegiatan yang berhubungan dengan lembaga seperti pelatihan ataupun workshop, maka instruktur kursus yang bertugas mengajar pada saat itu 
terpaksa harus digantikan dengan instruktur lainnya yang terkadang bukan di bidang keahliannya, dan yang paling berpengaruh disaat kursus harus ditunda lain waktu karena tidak ada instruktur lainnya yang menggantikan, hal seperti ini akan sangat berpengaruh dengan kualitas kursus belajar peserta didik. Dengan adanya pembelajaran daring maka proses kursuspun akan tetap bisa dilaksanakan oleh instruktur kapanpun dan dimanapun dia berada.

b. InformationAnalysis (Analisa Informasi)

Pada sistem yang lama informasi mengenai materi kursus yang disampaikan secara langsung terkadang tidak diingat dengan baik oleh peserta didik, terutama bagi beberapa peserta didik yang malas untuk mencatat materi yang diberikan, dengan adanya Website E-Learning ini maka materi bisa dikirim ke peserta didik dan dilengkapi dengan video pembelajarannya sehingga mereka bisa langsung membaca materi dan menonton video tutorial yang tersedia untuk dapat dipraktekkan setelahnya sehigga informasi dari materi yang diberikan dapat berfungsi dengan baik.

c. Economy Analysis (Analisa Ekonomi)

Analisa dari segi ekonomi, pada sistem tatap muka selalu diadakan di lembaga kursus, dimana para instruktur dan peserta didik diwajibkan untuk datang sesuai kelas yang diikuti, yang berarti setiap menuju ke lembaga kursus selalu menghabiskan bahan bakar ketika dalam perjalanan, bagia yang berasal dari daerah harus menyewa rumah atau kost sebagai tempat tinggal sementara, dan mereka harus selalu membeli makan jika tidak berada jauh dari orang tua/wali terutama bagia yang tidak mempersiapkan perlengkapan masak atau bagi yang tidak bisa memasak sama sekali. Dari semua yang dicontohkan sebelumnya, penggunaan Website E-Learning menjadi jawaban yang tepat dalam menghadapi persoalan tersebut, dimana pengeluaran biaya bahan bakar menjadi berkurang, baik instruktur maupun peserta tidak perlu lagi melakukan perjalanan pulang-pergi karena pengguna Website E-Learning dapat digunakan dimana saja bahkan dirumah sekalipun. Bagi para peserta kursus yang berasal dari luar kota Tembilahan juga tidak perlu menyewa tempat tinggal selama mengikuti kursus dan tidak perlu setiap saat membeli makanan diluar. Dari pihak LKP OBY Komputer juga akan lebih hemat dalam biaya listrik bulanan karena tidak perlu banyak mengoperasikan komputer dan perangkat lainnya yang menggunakan daya listrik. Selain itu juga akan meningkatkan keuntungan pemasukkan karena selalu bisa menampung peserta didik walaupun dengan jumlah banyak tanpa harus memikirkan ruang kelas yang terbatas.

d. Control Analysis (Analisa Pengendalian)

Sistem pengendalian saat ini masih sangat lemah, disaat diberlakukan lockdown atau yang sekarng dikenal dengan istilah PPKM maka pihak lembaga tidak bisa berbuat apa-apa selain meliburkan kegiatan kursus, dengan adanyaWebsite E-Learningmaka hal seperti ini dapat diatasi oleh instuktur dengan metode belajar daring (online), sehingga program kursus tetap bisa berjalan walaupun tanpa harus tatap muka secara langsung. Hal ini juga sekaligus dapat membantu upaya pencegahan penyebaran Covid-19.

e. EficiencyAnalysis (Analisa Efesiensi)

Padsa sistem lama, membludaknya jumlah keinginan masyarakat untuk mengikuti kegiatan kursus sangat berpengaruh dengan sarana dan prasaran yang kurang memadai di lembaga kursus, sehingga banyak calon peserta yang harus mencari tempat kursus lain. Dengan penggunaan Website E-Learningakan sangat menguntungkan bagi lembaga karena bisa menerima banyaknya calon peserta yang ingin mengikuti kursus tanpa harus memikirkan sarana dan prasarana yang tersedia, hal ini menjadi lebih efisien dari segi tempat dan waktu karena dapat diakses dimanapun dan kapan saja.

f. Service Analysis (Analisa Pelayanan)

Pada sistem kursus secara tatap muka, banyak peserta didik yang malu untuk bertanya langsung kepada instruktur ketika materi yang diberikan kurang paham atau malu ketika berdiskusi dengan anggota kelas yang lain, sehinga mereka lebih memilih diam dan tidak ikut berinteraksi secara aktif dikelas, dengan adanya fitur live chat pada Website E-Learning maka 
peserta didik yang pemalu tersebut akan lebih bisa mengeluarkan pendapat dan jawaban untuk materi yang diberikan. Hal ini sangat berpengaruh kepada kepuasan peserta didik untuk mengikuti kursus pada lembaga tersebut.

\subsection{Perancangan Sistem}

Hasil perancangan sistem informasi Website E-Learning kursus komputer pada LKP OBY Komputer ini terdiri dari beberapa proses yang menggunakan permodelan diagram UML (Unified Modeling Language) yang terdiri dari Use Case Diagram, Activity Diagram, Sequence Diagram, Class Diagram dan Deployment Diagram.

Use Case adalah gambaran dari fungsionalitas suatu sistem sehingga pengguna sistem dapat mengerti dan memahami mengenai kegunaan sistem yang dibangun.Dalam pembuatan Website E- Learning ini peneliti menggambarkan 3 buah use casediagram yang tersiri dari Use Case admin, Use Case guru dan Use Case siswa seperti yang digambarkan. Berikut merupakan Use Case Diagram admin dalam Website E-Learning kursus komputer pada LKP OBY Komputer Tembilahan.

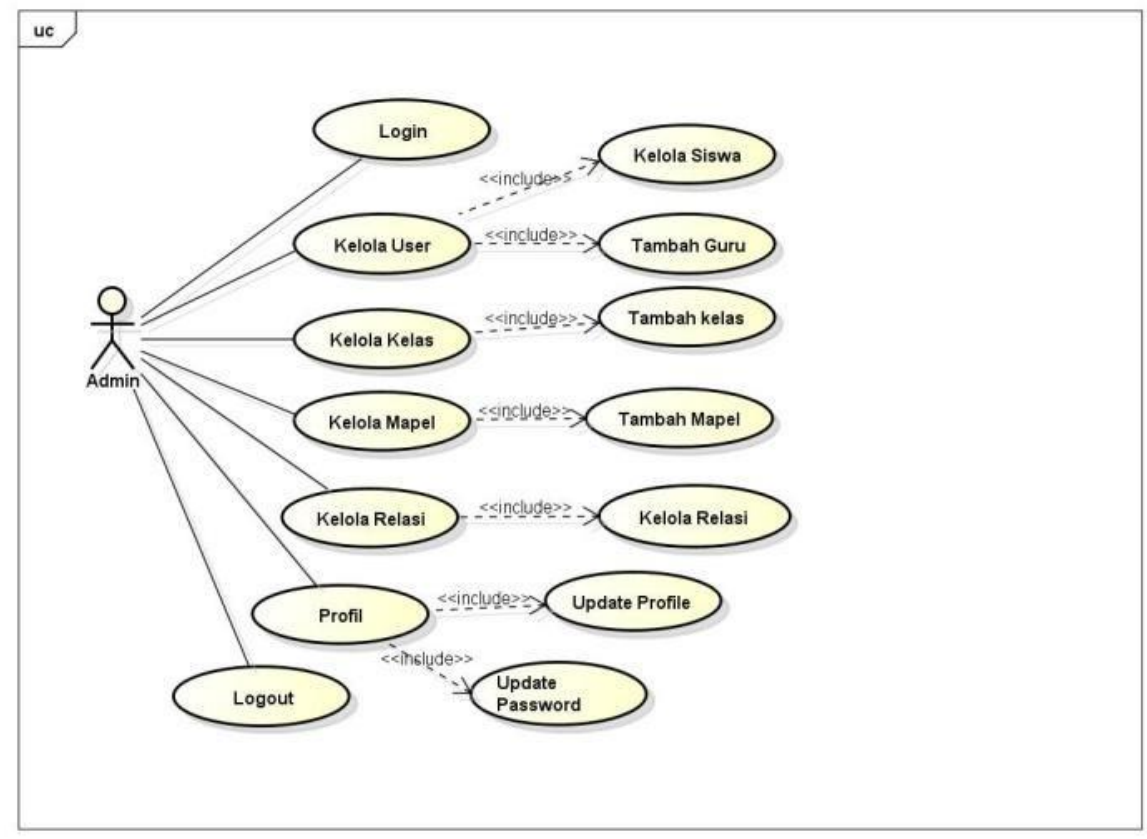

\section{Gambar 2. Use Case Diagram admin}

Pada gambar 2 menjelaskan bahwa admin dapat melakukan login kedalam website, didalam dashboard utama tersebut admin memiliki akses untuk mengelola user baik guru maupun siswa, mengelola kelas, mengelola mata pelajaran, mengelola relasi antara guru dengan mata pelajaran yang diajarkan sesuai bidang masing-masing, serta mengubah profil dan mengganti password.

Diagram yang menggambarkan kelas-kelas dalam sebuah sistem dan hubungannya antara satu dengan yang lain, yang didalamnya terdapat atribut dan operasi merupakan pengertian dari class diagram. Berikut merupakan class diagram dari website E-Learning kursus komputer di LKP OBY Komputer Tembilahan. 


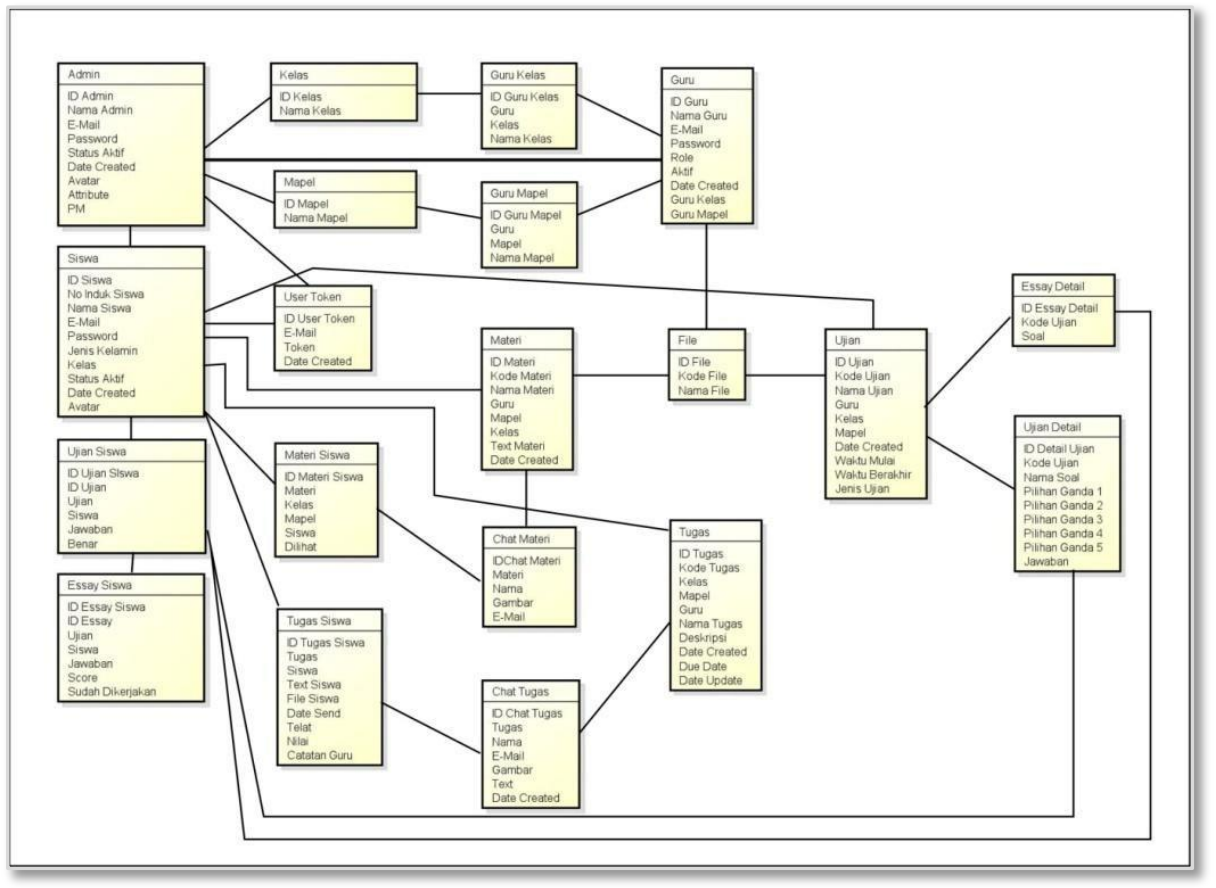

\section{Gambar 3. Class Diagram Website E-Learning}

Pada gambar 3 dijelaskan bahwa dalam pembuatan website E-Learning kursus komputer pada LKP OBY Komputer Tembilahan terdapat dua puluh database yang saling berhubungan.

Data Model untuk website E-Learning kursus komputer pada LKP OBY Komputer Tembilahan ini dapat dilihat pada gambar di bawah ini.

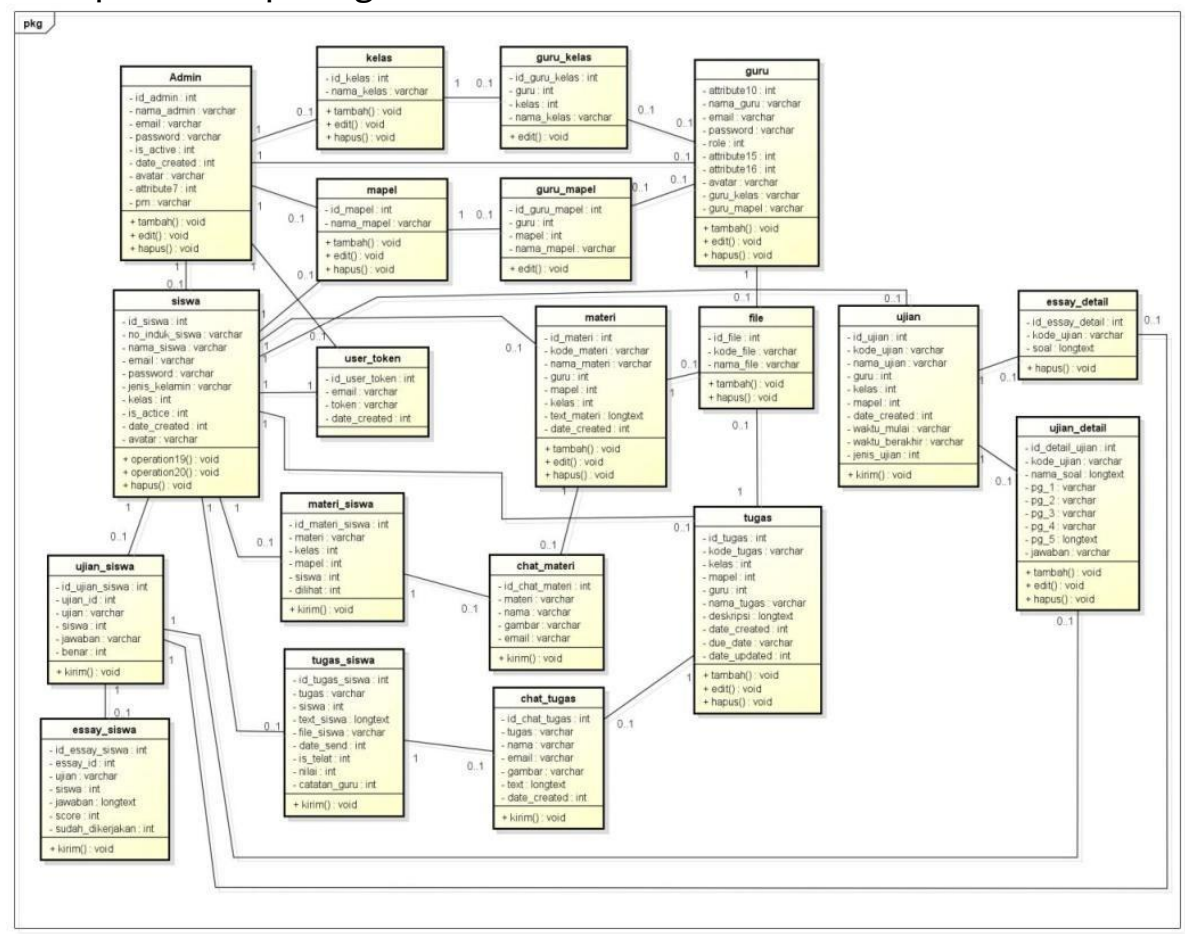

Gambar 4. Physical Data Model Website E-Learning

Pada gambar 4 terdapat dua puluh class yang saling berhubungan, dimana tiap-tiap class memiliki suatu hubungan dengan class lainnya yang menggambarkan adanya suatu aktivitas yang 
dilakukan dalam sistem.Contohnya admin dapat mengakses banyak class seperti class guru, siswa, dll.

\subsection{Hasil Implementasi}

Implementasi merupakan tahapan yang dilakukan untuk menyelesaikan desain sistem yang telah disetujui sebelumnya dengan tujuan untuk memastikan bahwa user dapat menggunakan atau mengoperasikan sistem baru. Hasil implementasi halaman admin website E-Learning kursus komputer pada LKP OBY Komputer dapat dilihat pada gambar berikut ini:

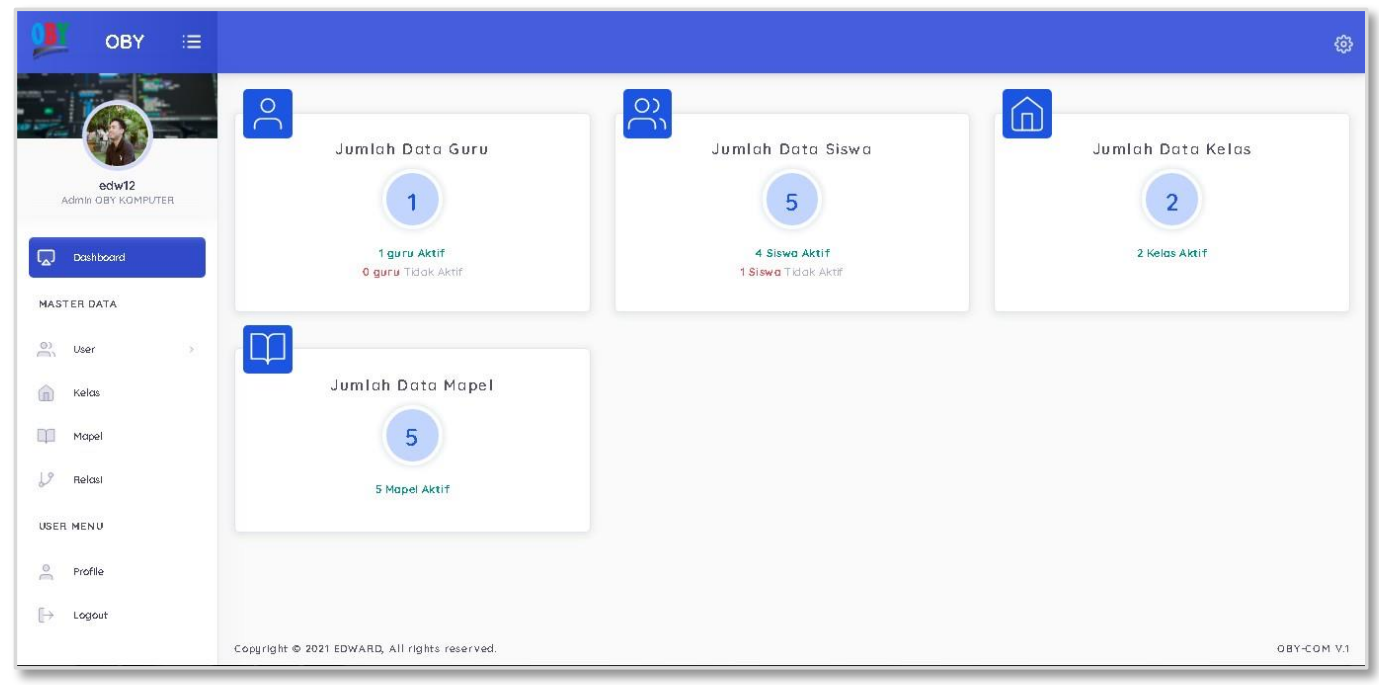

\section{Gambar 5. Tampilan halaman admin}

Gambar 5 merupakan tampilan halaman admin dari website E-Learning kursus komputer pada LKP OBY Komputer Tembilahan yang terdiri dari beberapa menu yaitu: dahsboard, user, kelas, mapel, relasi, profil dan logout. Hasil Implementasi dari halaman user siswa website E-Learning kursus komputer pada LKP OBY Komputer dapat dilihat pada gambar berikut ini:

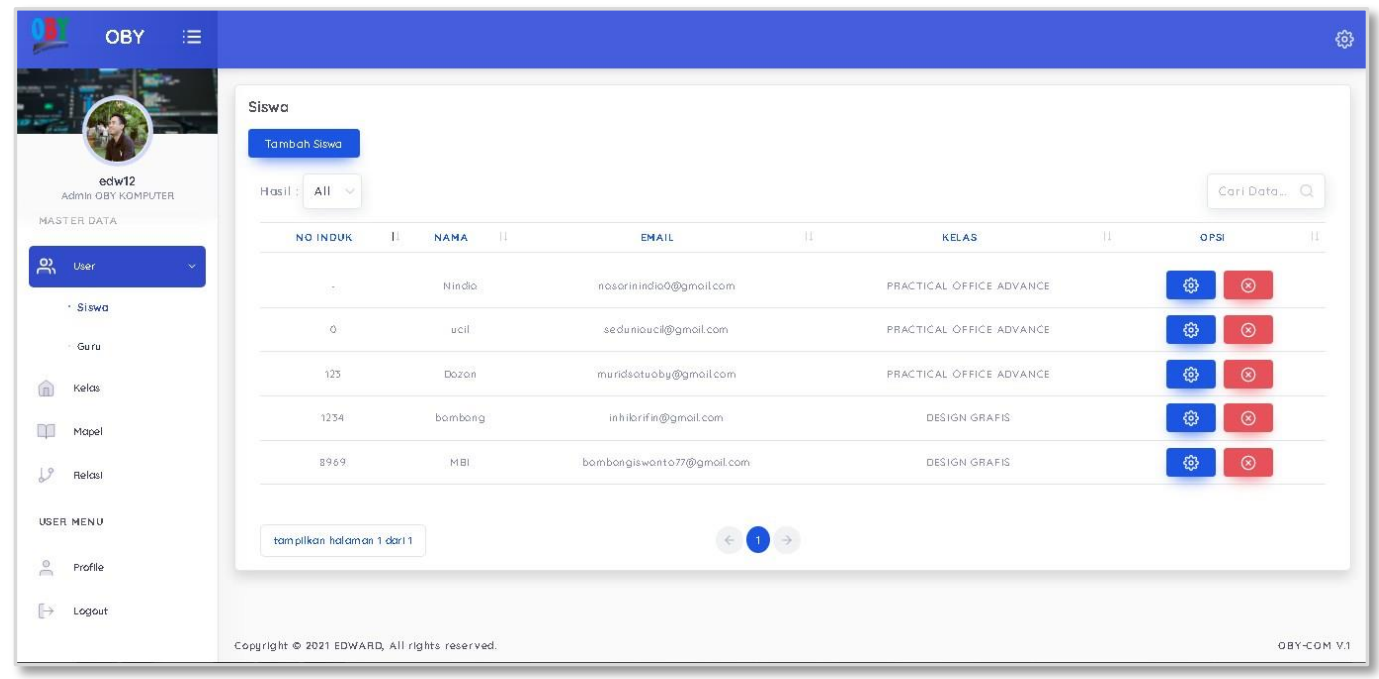

\section{Gambar 6. Tampilan halaman user siswa}

Gambar 6 merupakan tampilan halaman user siswa dari website E-Learning kursus komputer pada LKP OBY Komputer Tembilahan yang menampilkan beberapa informasi berupa: no.induk, nama, email dan kelas, serta dilengkapi aksi untuk manambah, mengedit dan menghapus data. Hasil Implementasi dari halaman user guru website E-Learning kursus komputer pada LKP OBY Komputer dapat dilihat pada gambar berikut ini: 


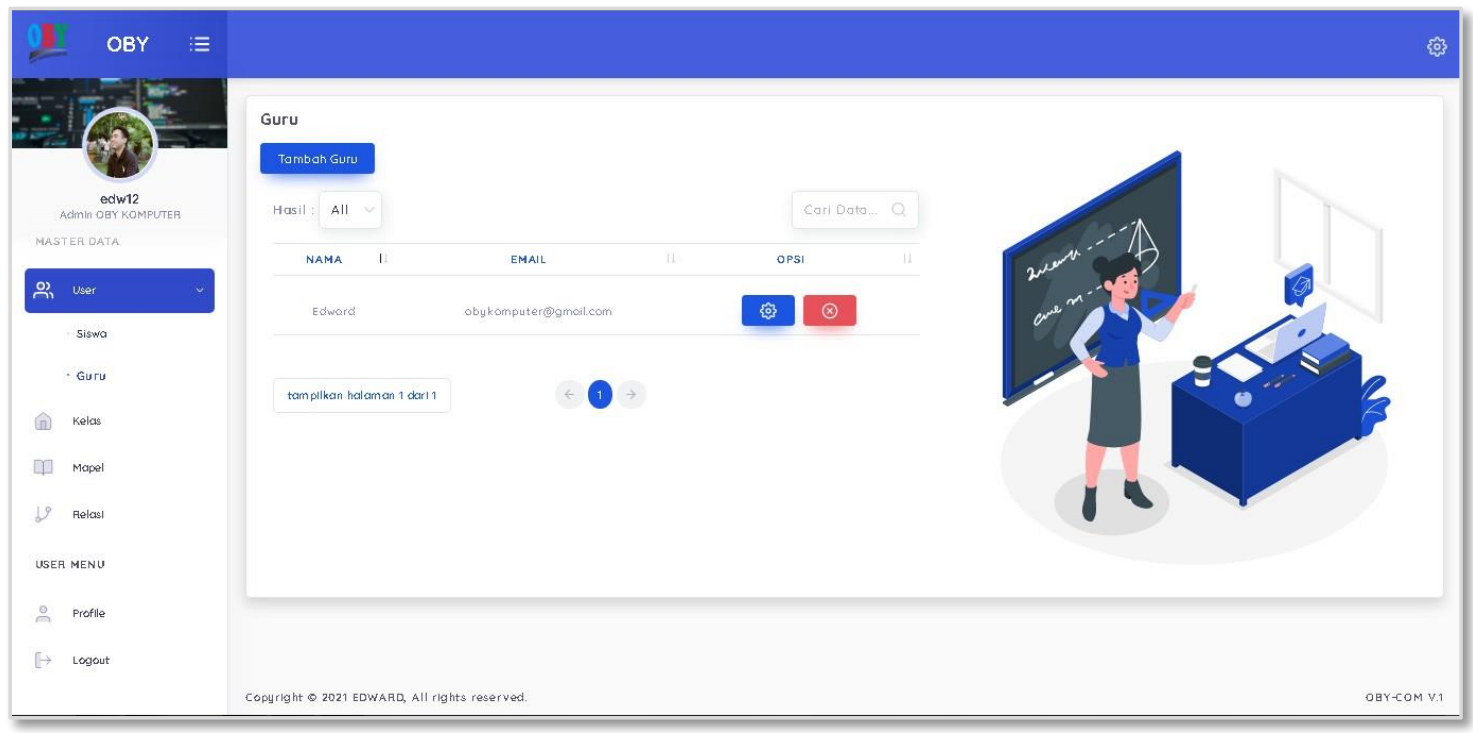

Gambar 7. Tampilan halaman user guru

Gambar 7 merupakan tampilan halaman user guru dari website E-Learning kursus komputer pada LKP OBY Komputer Tembilahan yang menampilkan beberapa informasi berupa: nama dan e-mail serta dilengkapi aksi untuk manambah, mengedit dan menghapus data. Hasil Implementasi dari halaman materi website E-Learning kursus komputer pada LKP OBY Komputer dapat dilihat pada gambar berikut ini:

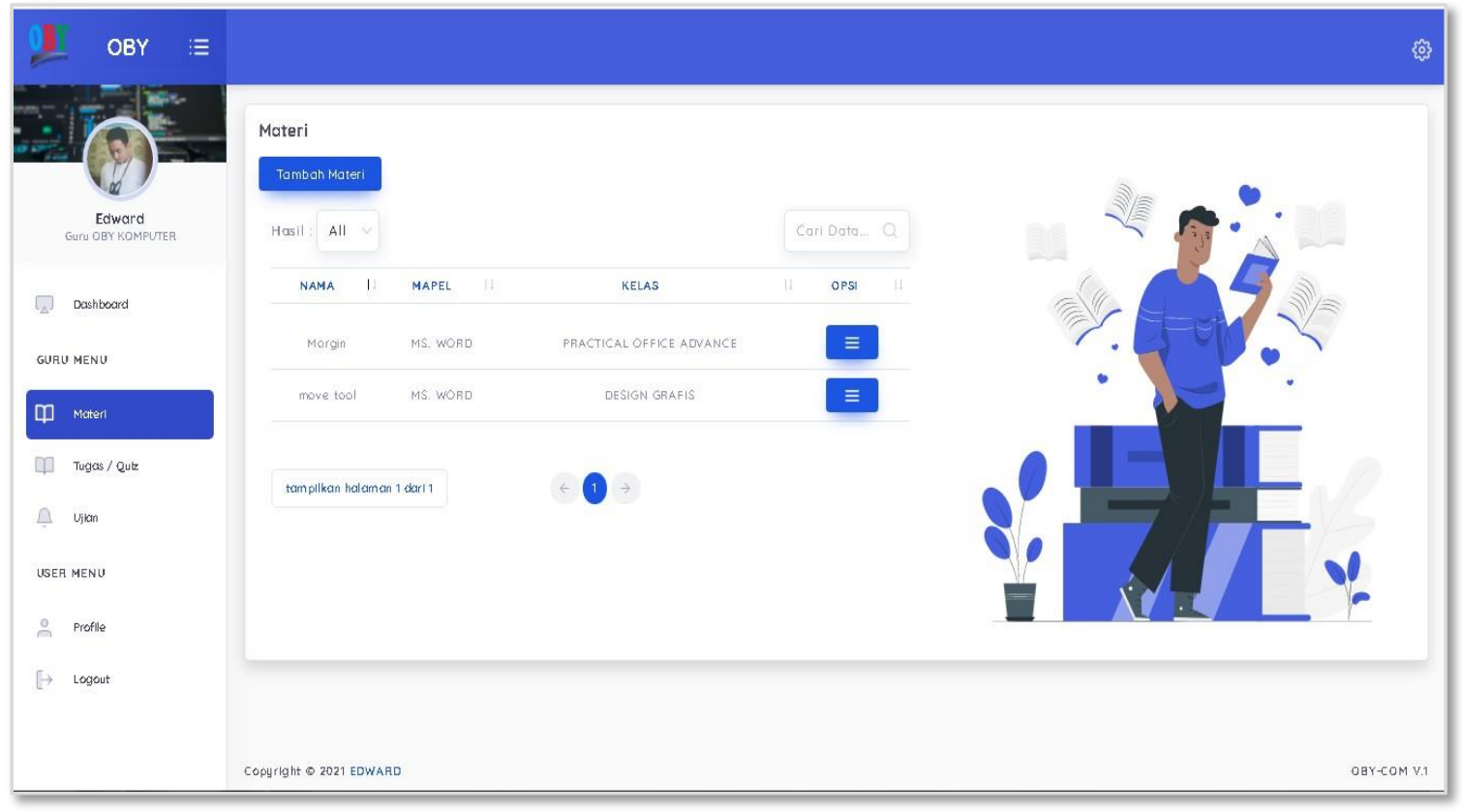

\section{Gambar 8. Tampilan halaman materi}

Hasil Implementasi dari halaman tambah tugas website E-Learning kursus komputer pada LKP OBY Komputer dapat dilihat pada gambar berikut ini: 


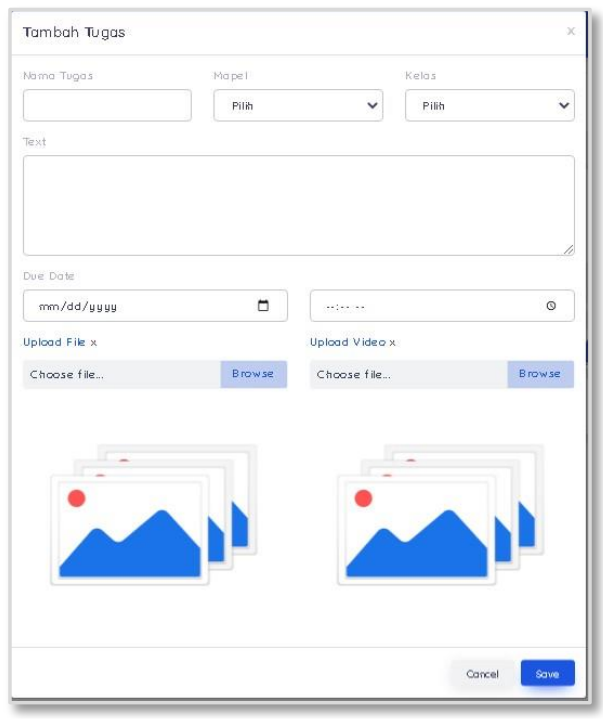

\section{Gambar 9. Tampilan halaman tambah tugas}

Gambar 9 merupakan tampilan halaman tambah tugas dari website E-Learning kursus komputer pada LKP OBY Komputer Tembilahan, digunakan oleh guru untuk menambahkan tugas dengan mengisi form nama tugas, memilih mata pelajaran, memilih kelas, mengisi kolom perintah tugas, menentukan tanggal dan waktu batas akhir pengumpulan tugas serta mengupload file maupun video tugas, jika sudah lalu menekan tombol save dan tugas akan terkirim. Hasil Implementasi dari halaman tambah ujian pilihan ganda website E-Learning kursus komputer pada LKP OBY Komputer dapat dilihat pada gambar berikut ini:

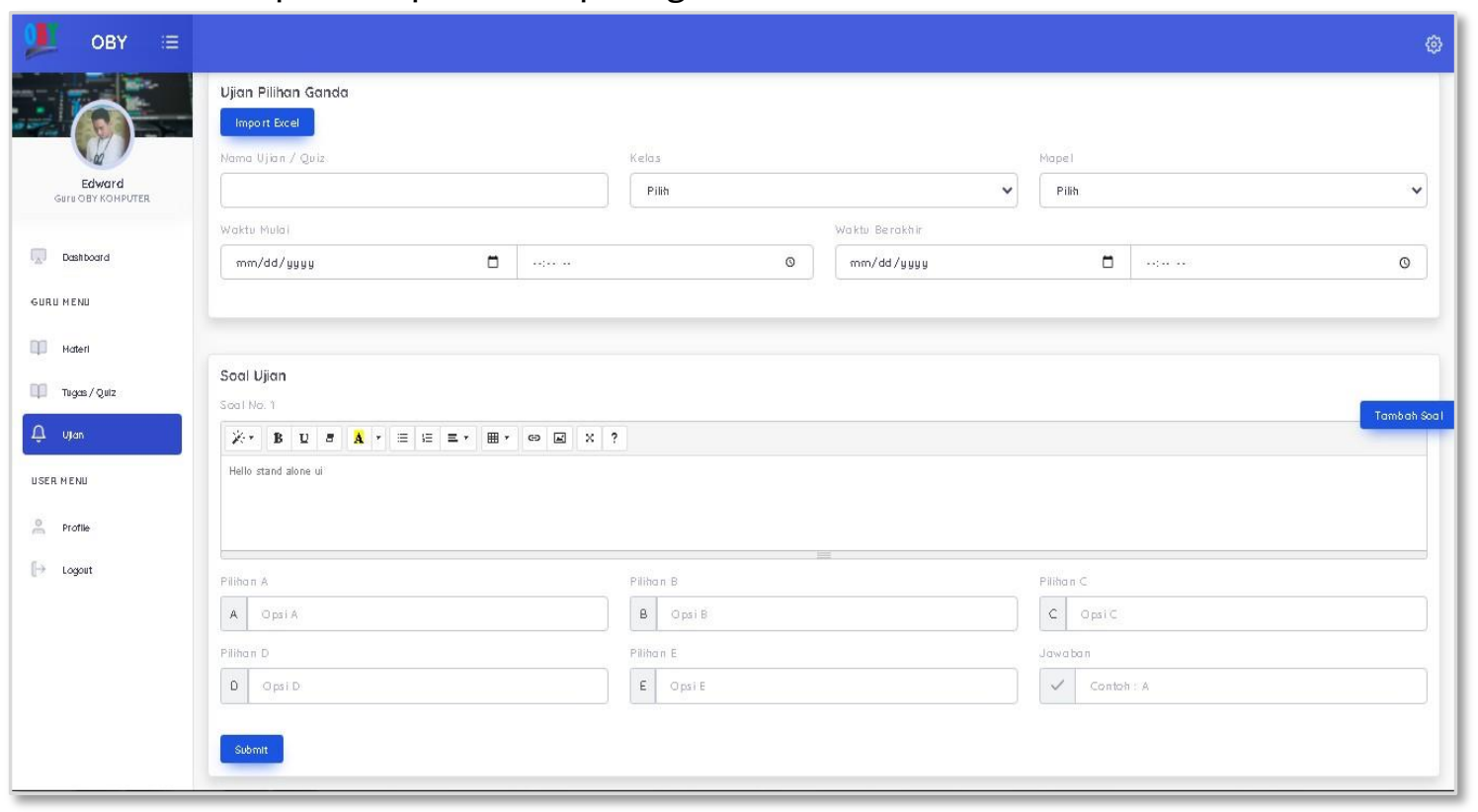

\section{Gambar 10. Tampilan halaman tambah ujian pilihan ganda}

Gambar 10 merupakan tampilan halaman tambah ujian pilihan ganda dari website E- Learning kursus komputer pada LKP OBY Komputer Tembilahan, digunakan oleh guru untuk menambahkan ujian berupa pilihan ganda dengan mengisi form nama ujian, memilihkelas, memilih mata pelajaran, menentukan tanggal dan waktu batas mulai dan berakhir ujian, mengisi form soal bererta pilihan jawaban, menentukan jawaban yang benar, kemudian menekan tombol tambah soal untuk mengulang pengisian soal berikutnya hingga selesai, jika sudah lalu menekan tombol 
submit dan ujian akan terkirim. Hasil Implementasi dari halaman tambah ujian essay website ELearning kursus komputer pada LKP OBY Komputer dapat dilihat pada gambar berikut ini:

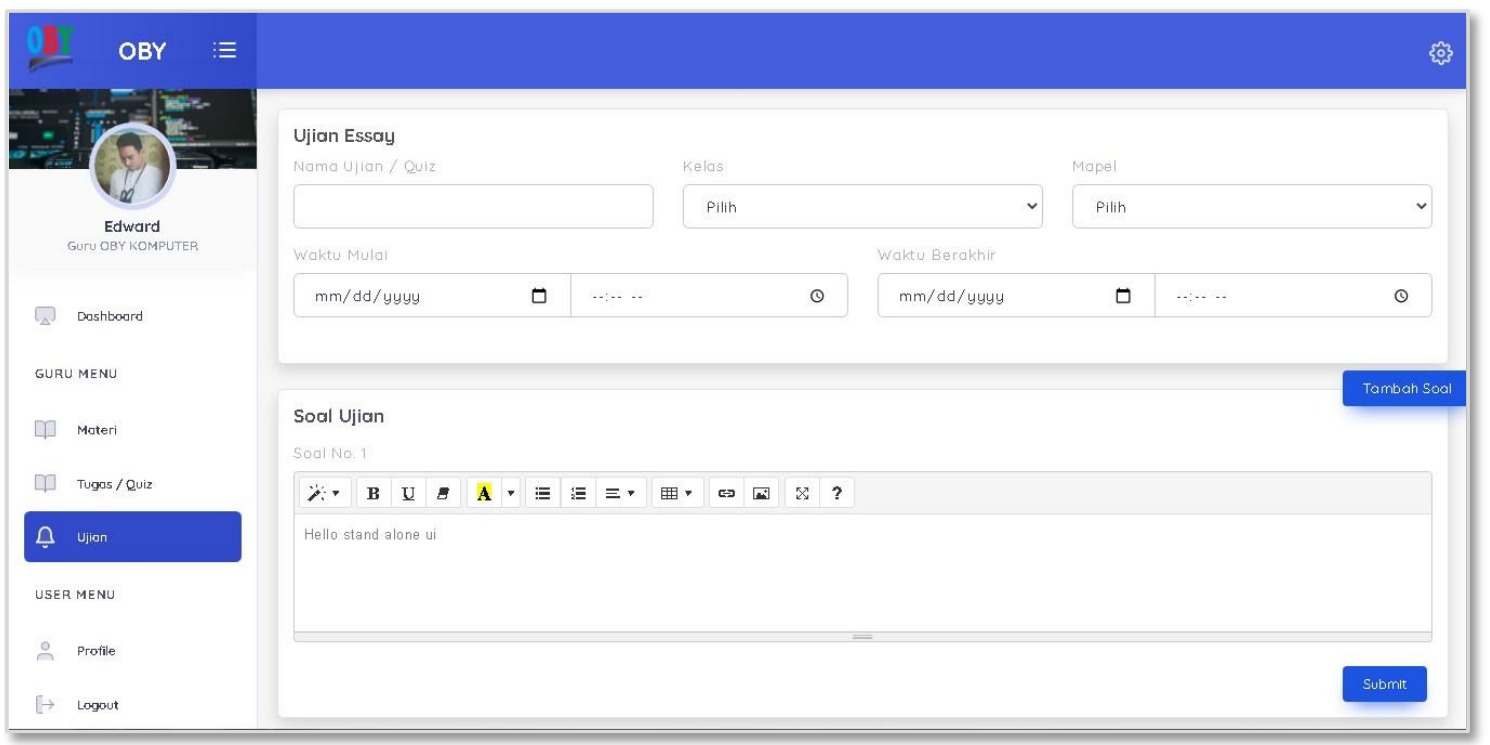

\section{Gambar 11. Tampilan halaman tambah ujian essay}

Gambar 11 merupakan tampilan halaman tambah ujian essay dari website E-Learning kursus komputer pada LKP OBY Komputer Tembilahan, digunakan oleh guru untuk menambahkan ujian berupa essay dengan mengisi form nama ujian, memilihkelas, memilih mata pelajaran, menentukan tanggal dan waktu batas mulai dan berakhir ujian, mengisi form soal, kemudian menekan tombol tambah soal untuk mengulang pengisian soal berikutnya hingga selesai, jika sudah lalu menekan tombol submit dan ujian akan terkirim. Hasil Implementasi dari halaman utama siswa website E-Learning kursus komputer pada LKP OBY Komputer dapat dilihat pada gambar berikut ini:

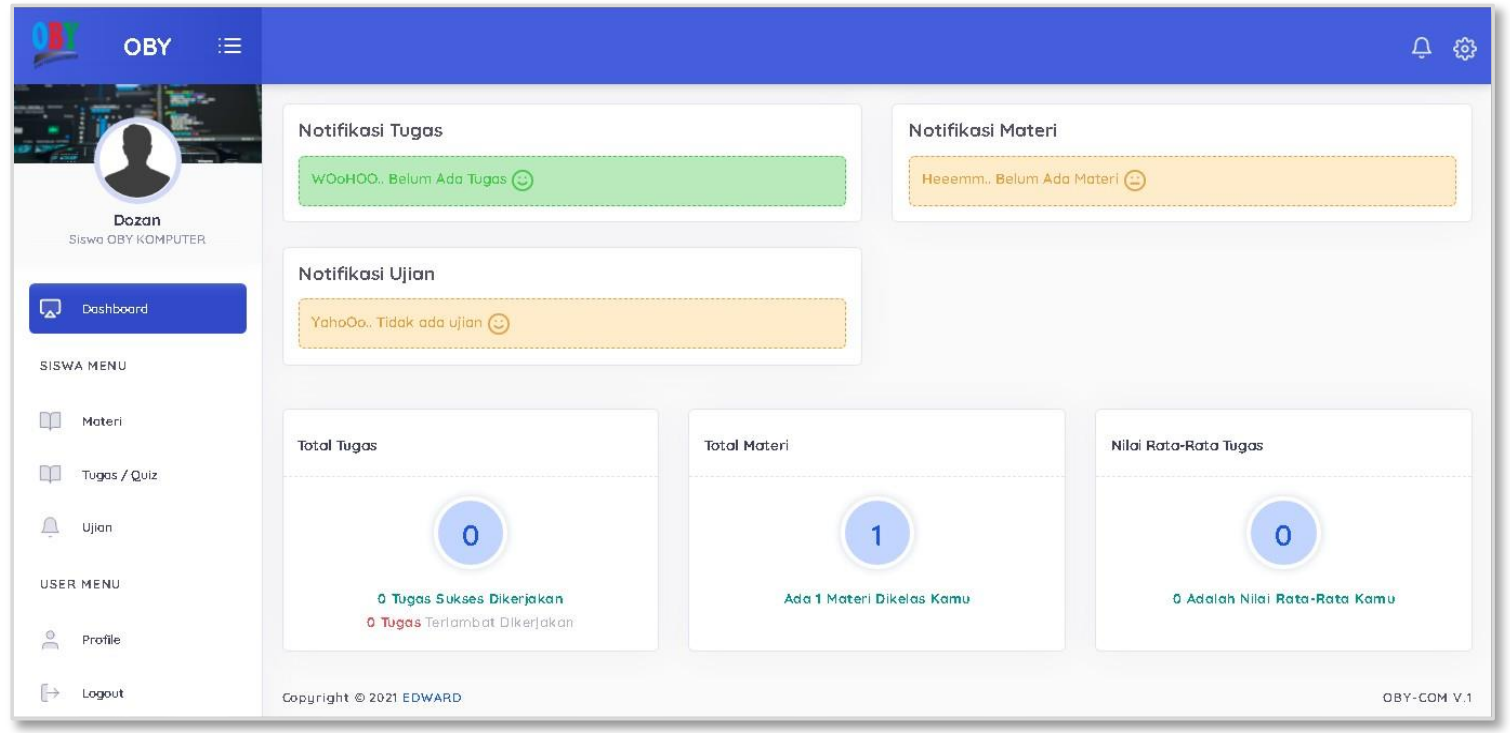

\section{Gambar 12. Tampilan halaman utama siswa}

Gambar 12 merupakan tampilan halaman utama siswa dari website E-Learning kursus komputer pada LKP OBY Komputer Tembilahan yang menampilkan notifikasi terkait materi, tugas dan ujian, pemberitahuan total materi dan tugas yang telah dikirimkan oleh guru dan nilai rata-rata tugas. Hasil Implementasi dari halaman lihat materi oleh siswa di website E-Learning kursus komputer pada LKP OBY Komputer dapat dilihat pada gambar berikut ini: 


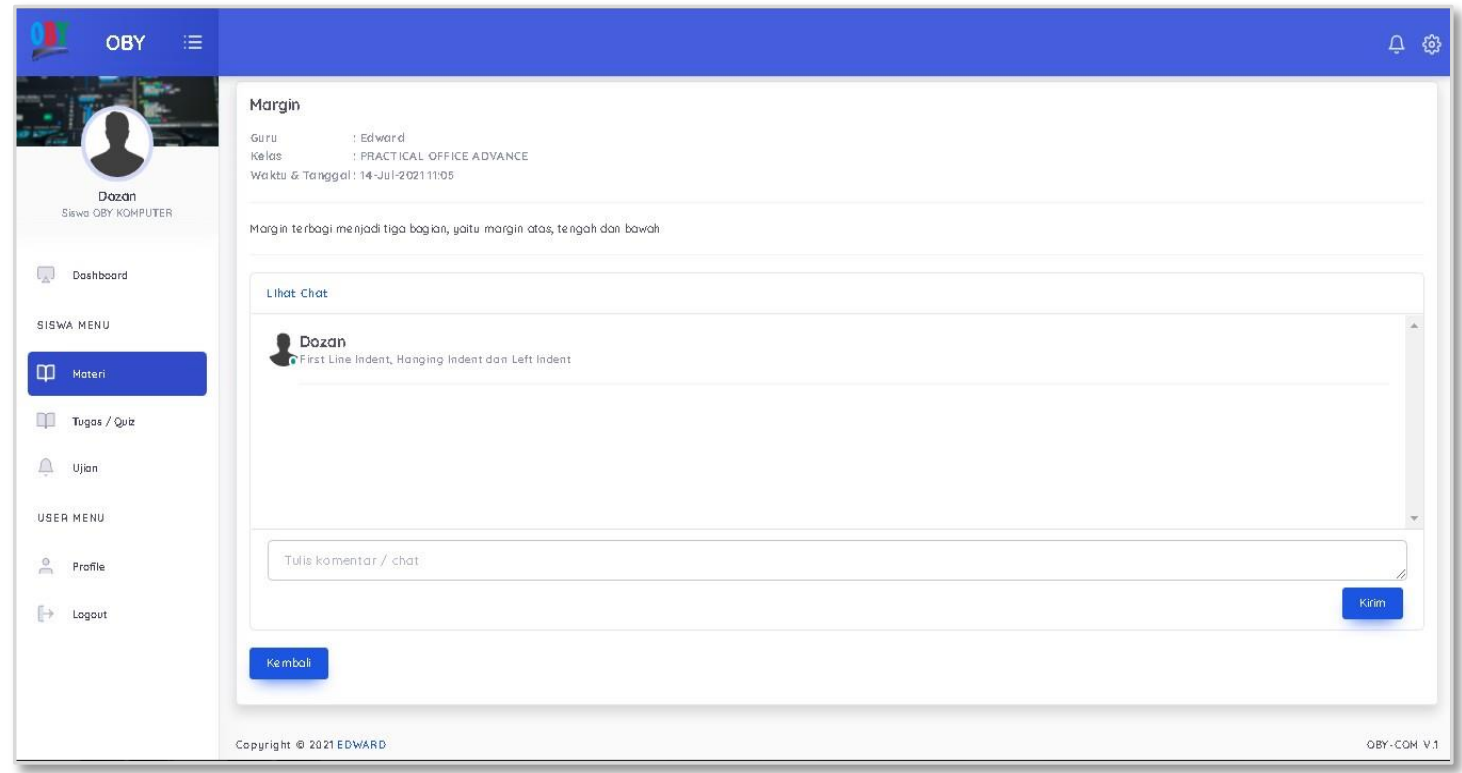

Gambar 13 Tampilan halaman lihat materi

Gambar 13 merupakan tampilan halaman lihat materi siswa dari website E-Learning kursus komputer pada LKP OBY Komputer Tembilahan yang menampilkan materi-materi yang telah dikirimkan oleh guru sesuai mata pelajaran, di halaman ini juga memungkinkan untuk melakukan live chat pada setiap anggota. Hasil Implementasi dari halaman lihat tugas oleh siswa di website E-Learning kursus komputer pada LKP OBY Komputer dapat dilihat pada gambar berikut ini:

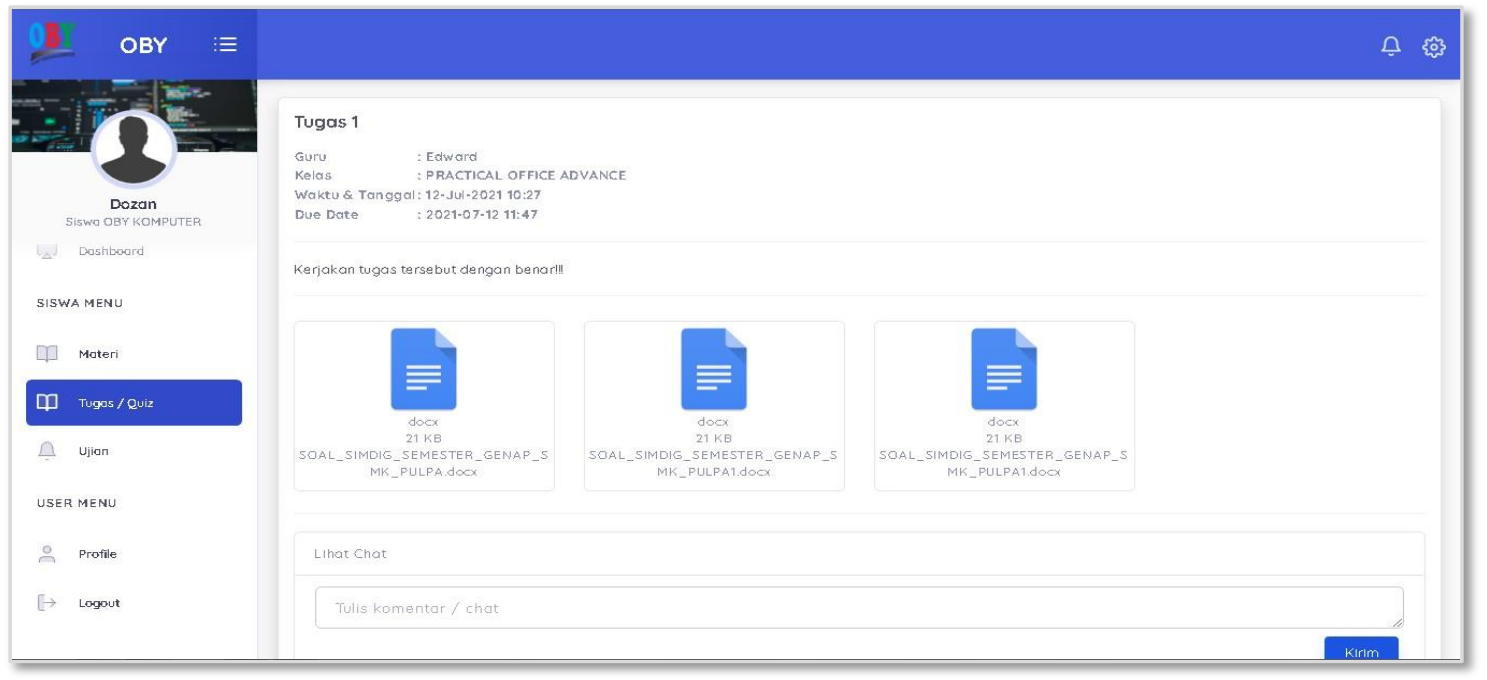

\section{Gambar 14 Tampilan halaman lihat tugas}

Gambar 14 merupakan tampilan halaman lihat tugas siswa dari website E-Learning kursus komputer pada LKP OBY Komputer Tembilahan yang menampilkan kumpulan tugas yang telah dikirimkan oleh guru sesuai mata pelajaran, di halaman ini juga memungkinkan untuk melakukan live chat pada setiap anggota. Hasil Implementasi dari halaman lihat ujian oleh siswa di website E-Learning kursus komputer pada LKP OBY Komputer dapat dilihat pada gambar berikut ini: 


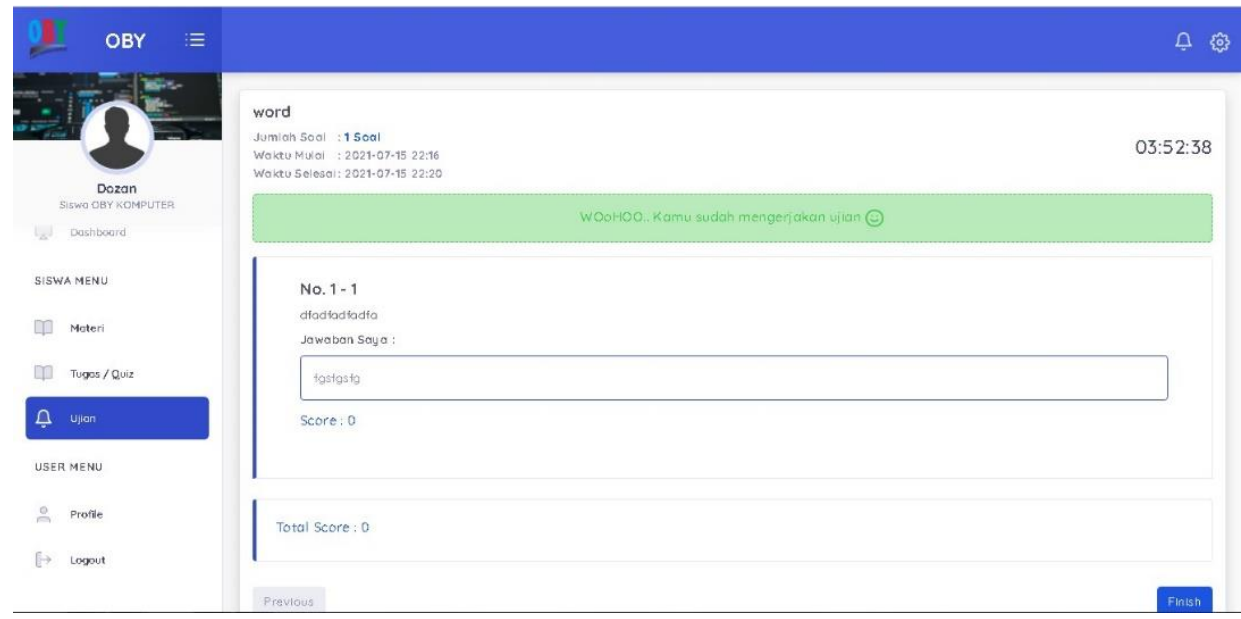

\section{Gambar 15 Tampilan halaman ujian}

Gambar 15 merupakan tampilan halaman ujian siswa dari website E-Learning kursus komputer pada LKP OBY Komputer Tembilahan yang menampilkan soal ujian yang telah dikirimkan oleh guru sesuai mata pelajaran.

\section{KESIMPULAN}

Kesimpulan dari penelitian Sistem Informasi Website E-Learning kursus komputer pada LKP OBY Komputer Tembilahan ini sebagai berikut:

1. Sistem Informasi Website E-Learning kursus komputer pada LKP OBY Komputer Tembilahan dapat mempermudah para peserta didik/siswa melalukan proses pembelajaran dengan menggunakan metode daring.

2. Dengan terimplementasikannya Sistem Informasi Website E-Learning kursus komputer pada LKP OBY Komputer Tembilahan ini menjadikan sarana pembelajaran baru yang belum pernah diterapkan oleh LKP OBY Komputer sebelumnya.

\section{REFERENSI}

[1] L. B. Mirnawati, "Pengaruh Model Pembelajaran Kooperatif Tipe Group Investigation Terhadap Kreativitas Mahasiswa Semester I PGSD UM Surabaya pada Mata Kuliah Pengantar Manajemen Pendidikan," Pedagog. J. Pendidik., vol. 6, no. 1, p. 84, 2017, doi: 10.21070/pedagogia.v6i1.598.

[2] M. P. Dr. H. Taqiyuddin, Modul Manajemen Pendidikan Nonformal Oleh. Cirebon, 2019.

[3] A. Setiawan, L. Nurlaela, S. Muslim, and E. Yundra, "Pengembangan E Learning Sebagai Media," no. September, pp. 52-56, 2019.

[4] O. J. F. Wassalam, R. Umar, and A. Yudhana, "Implementasi dan Pengembangan Sistem ELearning Berbasis Web Pada STMIK Muhammadiyah Paguyangan," Semin. Nas. Multi Disiplin Ilmu Call Pap., no. Call for Papers UNISBANK Ke-3, pp. 104-107, 2017, [Online]. Available: https://www.unisbank.ac.id/ojs/index.php/sendi_u/article/download/5002/1514/o.

[5] H. Kusniyati and Y. H. Mursidigama, "Aplikasi Kursus Komputer Online Menggunakan Php Pada," PETIR (Pengkajian dan Penerapan Tek. Inform., vol. 8, pp. 133-239, 2015.

[6] I. Wijaya and A. H. Lubis, "Perancangan Dan Pembuatan E-Learning Berbasis Moodle Pada Mata Pelajaran Keterampilan Komputer Dan Pengelolaan Informasi," J. Pendidik. dan Teknol. Inf., vol. 5, no. 1, pp. 61-70, 2018, [Online]. Available: http://www.moodle.org.

[7] I. H. G. Manurung, "Sistem Informasi Lembaga Kursus Dan Pelatihan (LKP) City Com Berbasis Web Menggunakan Php Dan Mysql," J. Mahajana Inf., vol. 4, no. 1, pp. 42-50, 2019. 